ПРАКТИЧНІ РЕКОМЕНДАЦІЇ ЩОДО РОЗВИТКУ ЕМОЦІЙНОГО ІНТЕЛЕКТУ У СТУДЕНТІВ ЗАКЛАДУ ВИЩОЇ ОСВІТИ НА ЗАНЯТТЯХ 3 АНГЛІЙСЬКОї МОВИ

\title{
PRACTICAL RECOMMENDATIONS FOR DEVELOPMENT UNIVERSITY STUDENTS' EMOTIONAL INTELLIGENCE AT ENGLISH LESSONS
}

у статті розглядається роль емоцій у
житті людини, наголошується на зв'язку
емоційної та мотиваційної соер. Виклада-
ються теоретичні основи дослідження: про-
водиться аналіз праць учених, присвячених
визначенню емоцій, їхній класифрікації, опису
трьох ключових елементів емоцій: суб'єк-
тивного сприймання, орізіологічної реакції
та поведінкової відповіді. Наголошується
на ролі соціокультурних норм поведінки у
вираженні й інтерпретації емоцій. Розмеж-
овуються терміни «емоція» та «настрій».
Автором вивчається поняття «емоційний
інтелект», його складники, взаємозв'язок
з академічними досягненнями. Підкреслю-
ється, що емоційний інтелект допомагає
справитися з негативними емоціями та
поведінкою, зумовленою впливом цих емоцій.
Описуються риси студентів із високим емо-
ційним інтелектом. На основі аналізу теоретичного матеріалу про виникнення та сутність емоцій $і$ аналізу наявних методик розвитку емоційного інтелекту автор пропонує рекомендації щодо формування емоційного інтелекту на заняттях з англійської мови. Автор підкреслює, що необхідно формувати ставлення до оцінки як до засобу зворотного зв'язку, а не приговору чи методу покарання; чітко ставити мету та завдання курсу, тем та підтем, щоб студенти розуміли, яких знань та навичок вони мають набути до кінця вивчення курсу (окремої теми), який обсяг завдань їм необхідно виконати; давати студентам право вибору під час визначення тем дискусій, повідомлень чи презентацій; організовувати групові орорми роботи із чітким розподілом ролей, що дасть кожному можливість відчути свою значущість та причетність до загального успіху, зблизить студентів академічної групи. Автор також рекомендує пропонувати студентам вести щоденники, що допоможе їм покращити метакогніцію шляхом спостереження за перебігом власних думок, виявів емоцій та поведінкових патернів; вчити студентів описувати свій емоційний стан, обговорювати його причини; формувати у студентів навички активного слухання; вчити студентів завжди дякувати іншим людям за підтримку, допомогу, гарні поради. На думку автора, сприяє розвитку емоційного інтелекту застосування гумору на заняттях, адже гумор завжди викликає позитивні емоції. Рекомендується також створювати образ педагога як людини, мета якої-допомогти опанувати нові знання та навички, підтримати в разі виникнення труднощів; бути готовим емоційно підтримати студентів у разі стійкого поганого настрою, нападів злості, страху, тривоги без наявних зовнішніх стимулів.
Ключові слова: емоції, настрій, емоційна ссрера, емоційний інтелект, тривожність, cmpec.

The article deals with the role of emotions in the life of people. The author emphasizes the relations between emotional and motivational spheres. Theoretical basics of the research are outlined: the studies devoted to emotions determination, their classification and description of three key elements of emotions: subjective perception, physiological reaction and behavioral response are analyzed. The role of sociocultural norms of behavior in expressing and interpretation of emotions is stressed. The terms "emotion" and "mood" are differentiated. The notion "emotional intelligence", its elements and relation between emotional intelligence and academic achievements are researched. It is emphasized that emotional intelligence helps to cope with negative emotions and behavior that appears under influence of these emotions. The features of students that have high emotional intelligence are described.

The author offers recommendations on emotional intelligence formation at the English language lessons on the basis of analysis of theoretical material on the emotion appearance and character and analysis of existent methodologies of emotional intelligence formation. The author stresses that it is necessary to build attitude to grades as to the means of feedback, but not a verdict or the method of punishment; clearly set the aim and the tasks of the course, themes and subthemes to make the students understand, what knowledge and skills they are to achieve to the end of the course (a theme), what set of tasks they are to do; give the students the right of choice while determining the themes for discussion, reports or presentations; organize group forms of work with clear role distribution that gives everybody opportunity to feel their significance and feel themselves as a part of group success, makes closer the students of an academic group. The author also recommends the students to keep diaries that will help them to improve metacognition by observing their thoughts, expression of emotions and behavioral patterns; build the students' skills of active listening; teach students always to be grateful to other people for support help, good advice. To the author's mind, the use of humor at the lessons helps develop emotional intelligence, because humor always causes positive emotions. It is also recommended to create the teacher's image as a person whose aim is to help gain new knowledge and skills, support in case of difficult situations; be ready to support the students emotionally in case of stable bad mood, fits of anger, fear, anxiety without external incitements.

Key words: emotions, mood, emotional sphere, emotional intellect, anxiety, stress.
Емоції людини відіграють ключову роль у її житті. Ми часто ухвалюємо рішення, виконуємо чи не виконуємо ту чи іншу діяльність залежно від того, почуваємося ми щасливими, радісними, сумними, роздратованими, злими, розчарованими, знудженими; будуємо взає- 
мини з людьми залежно від емоцій, які ми до них відчуваємо. Часте переживання позитивних емоцій приводить до гарного настрою, позитиву, до бажання братися за нові справи, вирішувати питання, до позитивного впливу на людей. 3 іншого боку, часте переживання негативних емоцій призводить до поганого настрою, небажання щось робити, до виміщування свого поганого настрою на інших людях. Ось чому дуже важливо навчитися розуміти та керувати своїми емоціями.

Вивчення емоційної сфери людини було та залишається в центрі уваги науковців, адже розуміння природи емоцій дає можливість допомогти людям керувати своїми емоціями, долати стресові та депресивні стани, а якщо взяти до уваги тісний зв'язок емоційної сфери з мотиваційною, знання про причини виникнення емоцій та засоби впливу на них дадуть змогу покращити академічні результати студентів.

Актуальність дослідження зумовлюється суперечностями між вродженим характером емоцій та дуже неодноманітною емоційною реакцією різних людей на схожі зовнішні подразники, між потужним впливом емоцій на всі інші сфери життя людини та невеликою увагою, яка приділяється формуванню емоційного інтелекту у студентів закладу вищої освіти (далі - ЗВО). Дослідження емоційної сфери людини відбувається в різних напрямах: тлумачення виникнення емоцій (В. Джемс, Г. Ланге, В. Кеннон, Ф. Бард, П. Сімонов, С. Шехтер), класифікації емоцій (П. Екман), вивчення емоційної спрямованості особистості (Є. Ільїн, Б. Додонов), опис розвитку емоційної сфери в онтогенезі (Л. Божович, О. Запорожець), класифікація функцій емоційної сфери (Т. Кириленко).

Метою дослідження $€$ вивчення й узагальнення теоретичних і практичних досліджень емоційної сфери людини, розроблення практичних рекомендацій щодо формування емоційного інтелекту студентів 3ВО.

Емоції виникають під впливом зовнішніх подразників. Фізіологічним механізмом емоцій $€$ функціонування підкоркових нервових центрів - гіпоталамуса, лімбічної системи, ретикулярної формації. Емоційний інтелект це здатність розуміти власні емоції, управляти ними, а також розуміти та впливати на емоції інших людей.

Емоції мають такі властивості: (1) якість зміст переживання (радість, піднесення, захопленість, сум, тривожність, роздратування, страх, розпач, розчарування); (2) полярність - наявність у переживання протилежного (піднесення - пригніченість, радість - горе); (3) амбівалентність - інтеграція кількох протилежних елементів в одному переживанні (ревнощі поєднують любов і ненависть); (4) інтен- сивність - сила емоції; (5) тривалість - тривалі чи короткочасні.

Емоції - це комплекс фізіологічних станів, який складається із трьох компонентів: суб'єктивне переживання (досвід), фізіологічна реакція та поведінкова чи експресивна відповідь [8]

Протягом багатьох років науковці намагалися визначити основні види емоцій та класифікувати їх. Пол Екман виділив шість основних емоцій, які $€$ загальними для всіх культур, як-от: страх, огида, злість, здивування, щастя, сум [6]. Згодом Пол Екман розширив свій список базових емоцій, додав такі емоції, як спантеличеність, схвильованість, зневага, сором, гордість, задоволеність та веселість. Роберт Плутчик запропонував іншу систему класифікації емоцій, яка показувала, як різні емоції можуть поєднуватися та змішуватися разом. Це можна порівняти з тим, як художник змішує різні кольори для отримання нових [11]. Р. Плутчик запропонував вісім основних емоційних вимірів: щастя - сум; злість - страх; довіра - огида; здивування - очікування. Ці емоції можуть комбінуватися й утворювати нові. Наприклад, у результаті змішування щастя й очікування отримуємо схвильованість.

Для кращого розуміння суті емоцій сфокусуємося на їхніх трьох ключових елементах: суб'єктивне сприймання, фізіологічна реакція та поведінкова відповідь.

Хоча, з одного боку, емоції є вродженим явищем та притаманні людині незалежно від належності до певної культури, тих чи інших соціальних верств, її походження чи виховання, з іншого боку, вони є дуже суб'єктивними [3]. Візьмемо як приклад радість. Та сама подія може в одних людей викликати легке почуття радості, вираженої легкою посмішкою, а в інших почуття радості буквально їх переповнює. Так само емоція злості може варіювати від легкого переживання роздратування до нестерпної люті. Розрізняють емоції і за тривалістю. Ті самі події можуть в одних людей викликати злість на кілька секунд, а в інших - на пів години. Життєві ситуації часто викликають змішані емоції, як-от здивування та тривожність. Людина може водночас бути схвильованою та спантеличеною, задоволеною та щасливою. Змішані емоції можуть виникати одночасно (до того ж вираженість кожної емоції різниться) або можуть дуже швидко змінювати одна одну.

Емоції тісно пов'язані з фізіологією та спричиняють фізіологічні реакції, наприклад серцебиття, урчання в животі, почервоніння шкіри, спітніння долонь.

Багато фізіологічних реакцій, які супроводжують емоційні стани людини, регулюються симпатичною нервовою системою, яка $€$ частиною автономної нервової сис- 
теми. Автономна нервова система контролює мимовільні реакції організму, як-от кровоток і травлення. Симпатична нервова система контролює реакції боротьби чи втечі. У разі зустрічі людини із загрозою такі відповіді автоматично готують людину до втечі від небезпеки чи активної оборони.

Якщо ранні дослідження психології емоцій концентрувалися на автономних реакціях, то пізніші націлені на вивчення ролі мозку в емоціях. Дослідження мозку довели, що мозочкова мигдалина, частина лімбічної системи, відіграє важливу роль у виникненні емоцій, зокрема страху [12]. Мозочкова мигдалина це крихітна мигдалеподібна структура, пов'язана з мотиваційними станами, як-от голод чи відчуття спраги, а також з пам'яттю й емоціями. Мозочкова мигдалина стає активною, коли людина стикається з різними загрозами.

Серотонінергічна система відіграє важливу роль у послабленні наслідків стресу, бере участь у регуляції емоцій, апетиту, температури тіла, є хімічним посередником у синапсах лімбічної системи мозку.

У разі стресу підвищується активність серотонінергічних нейронів, що призводить до збільшення потреби в серотоніні та до нестачі серотоніну [4]. Серотонін нормалізує репаративні процеси в центральній нервовій системі (далі - ЦНС) та покращує психовегетативний статус.

Вплив стресорів на організм зменшує кількість серотонинових рецепторів у відділах ЦНС, відповідальних за регуляцію мозкового кровообігу і формування страху та тривоги. У разі дистресу реакція організму супроводжується зміною поведінкових механізмів із можливим розвитком станів тривоги, злості, страху та депресії [2]. Участь у стрес-реакціях такожберутьпериферичністрес-лімітуючісистеми (далі - СЛС), антиоксидантна система, система простагландинів та система NO.

Порушення СЛС під впливом стресорів призводить до порушення центральної та периферичної гемодинаміки. У разі стресу в деяких областях головного мозку спостерігається збільшення активності нейронів та збільшення кровотоку, а в разі дистресу спостерігається зменшення кровотоку в тих же областях головного мозку. Такі нейросудинні реакції призводять до когнітивної дисфункції та депресії [5].

Стресостійкість - це здатність протистояти впливу стресорів без розвитку функціональних змін в організмі. Стресостійкість підтримується СЛС, а також роботою механізмів адаптації, що реалізуються через взаємодію серцево-судинної системи (далі - ССС) та вегетативної нервової системи (далі - ВНС). Дані про механізми стресостійкості є теоретичною основою для створення нових мето- дик, спрямованих на профілактику та лікування стресу.

Третім компонентом є найбільш видимий вираження емоцій. Наша здатність розуміти вираження емоцій та впливати на них пов'язується з емоційним інтелектом. Це вираження проявляється в жестах, виразах обличчя, поведінці.

Дослідження свідчать, що багато виражень емоцій $€$ універсальними, як-от сміх та посмішка для вираження радості. Соціокультурні норми поведінки також відіграють роль у вираженні й інтерпретації емоцій. В західних культурах люди частіше виражають негативні емоції у присутності інших людей, тоді як у східних люди зазвичай виражають негативні емоції, коли вони перебувають на самоті. Мешканці південних країн більш імпульсивно виражають емоції порівняно з народами північних країн.

Терміни «емоція» та «настрій» часто вживаються як синоніми. Проте психологи пояснюють, що емоції є короткостроковими та мають явну чи неявну причину. Настрій є більш довготривалим станом. Часто немає явної причини настрою. Так, людина може почуватися кілька днів упоганому настрої без явної на те причини.

Емоційний інтелект - це здатність ефективно та позитивно ідентифікувати, оцінювати, контролювати, виражати емоції. Особистість із високим емоційним інтелектом здатна краще комунікувати, зменшувати тривожність та рівень стресу, урегульовувати конфліктні ситуації, покращувати відносини з іншими людьми, краще відповідати на виклики життя. Емоційний інтелект допомагає справитися з негативними емоціями та поведінкою, яка виникає під впливом цих емоцій. Учені наголошують на взаємозв'язку між емоційним інтелектом і академічними досягненнями [7]. Людина, яка перебуває у стані стресу, яку часто охоплює тривожність, яка часто перебуває в поганому настрої, не може сконцентруватися на навчальному матеріалі, вона може розуміти, що це їй потрібно, але не здатна розпочати виконання завдань. І навпаки, мотивація й академічні результати стають кращими, якщо студенти не просто будуть розуміти, що це потрібно зробити, а вони хотітимуть цим займатися, отримуватимуть емоційне задоволення від процесу навчання та результатів роботи.

Емоційний інтелект охоплює: (1) емоційну грамотність (розуміння власних відчуттів та відчуттів інших); (2) керування емоціями (уміння ефективно контролювати емоції).

Студенти з високим емоційним інтелектом $€$ позитивними (не скаржаться з найменшого приводу, знаходять рішення проблем), розуміють характер інших людей, розбираються у власних відчуттях та відчуттях інших людей, 
приймають зміни у своєму житті, швидко адаптуються до цих змін, мають гарні комунікативні навички, уміють переконувати людей, працюють над своїми слабостями та знають свої сильні сторони.

На основі аналізу теоретичного матеріалу про виникнення та сутність емоцій і аналізу наявних методик розвитку емоційного інтелекту ми пропонуємо рекомендації щодо формування емоційного інтелекту на заняттях з іноземної мови.

Необхідно формувати ставлення до оцінки як до засобу зворотного зв'язку, а не приговору чи методу покарання. Для цього потрібно проводити аналіз усних відповідей та письмових робіт, акцентувати увагу на тому, на що необхідно звернути увагу, щоб уникнути зроблених помилок у майбутньому.

Чітко ставити мету та завдання курсу, тем та підтем, щоб студенти розуміли, яких знань та навичок вони мусять набути до кінця вивчення курсу / окремої теми, який обсяг завдань їм необхідно виконати. Це допоможе їм скласти власний план опрацювання тем та відчувати емоційне піднесення під час виконання пунктів цього плану.

Давати студентам право вибору під час визначення тем дискусій, повідомлень чи презентацій. Це надасть студентам відчуття, що їм нічого не нав'язують, що вони є суб'єктом навчального процесу.

Організація групових форм роботи із чітким розподілом ролей дасть кожному можливість відчути свою значущість та причетність до загального успіху, зблизить студентів академічної групи. Завдяки цьому вони зможуть ближче познайомитися, емоційно підтримувати та допомагати одне одному в навчанні чи у складних обставинах, брати участь у навчальних проєктах та заходах поза межами аудиторії.

Наступною рекомендацією $є$ пропозиція студентам вести щоденники. Це допоможе їм покращити метакогніцію шляхом спостереження за перебігом власних думок, виявів емоцій та поведінкових патернів. Тривожність часто породжується через негативні розмови із собою [9]. Вправи, спрямовані на вивчення себе, своїх думок, відчуттів, зможуть припинити цей ірраціональний процес.

Для розвитку емоційного інтелекту необхідно вчити студентів описувати свій емоційний стан, обговорювати його причини.

Для формування емоційного інтелекту важливо розвивати у студентів навички активного слухання: уважно слухати співрозмовників, усвідомлювати свою та їхню невербальну поведінку, адекватно реагувати на почуте, висловлювати емоційну підтримку шляхом розділення радості чи висловлення слів підбадьорювання або співчуття в разі виникнення негативних емоцій.
Необхідно вчити студентів завжди дякувати іншим людям за підтримку, допомогу, гарні поради. Це зменшить відчуття того, що світ байдужий до проблем окремих людей, сконцентрує увагу на добрих справах оточення, допоможе подолати старі образи.

Сприяє розвитку емоційного інтелекту застосування гумору на заняттях, адже гумор завжди викликає позитивні емоції. На заняттях з англійської можна читати й обговорювати анекдоти та жарти, гумористичні оповіді, спонукати студентів розповідати прочитані жарти, а також свої власні; розповідати про смішні епізоди із життя відомих людей та зі свого життя, провести міжнародний день гумору. Цікаво обговорювати гумористичні оповіді та жарти з погляду аналізу того, як саме досягається гумористичний ефект, які риси характеру найчастіше висміюються. Це не тільки створить позитивну атмосферу під час занять, але й ознайомить студентів з особливостями гумору різних культур, допоможе переоцінити деякі події із власного життя, подивитись на них із гумором, досягти емоційного зближення між членами групи, подолати стрес, а також допоможе розрядити напружену ситуацію в навчальному процесі та поза навчанням. Разом із відчуттям вдячності, надією та духовністю почуття гумору належить до набору стійкостей, яку позитивні психологи називають трансцендентальністю. Разом ці стійкості допомагають нам створити зв'язки зі світом та забезпечити сенс життя. Відчуття гумору корелює з іншими стійкостями, як-от мудрість та любов до навчання. Відчуття гумору приводить до гарного емоційного стану й оптимізму.

Розуміння та створення гумору потребує низки розумових операцій. Когнітивні психологи пропонують триступеневу теорію гумору: (1) уявити ситуацію жарту; (2) знайти невідповідність у множинних інтерпретаціях жарту; (3) розв'язати невідповідність, відкидаючи буквальні, несмішні інтерпретації, оцінити значення смішних [10].

Рекомендується діагностувати рівень володіння іноземною мовою, складати на основі результатів діагностики індивідуальні плани для кожного студента із зазначенням очікуваних результатів і термінів, у межах яких ці результати мають бути досягнуті. Оцінка має враховувати прогрес кожного студента. Це допоможе уникнути негативних емоцій студентам із низьким рівнем володіння мовою, які на перших етапах не зможуть виконувати складних завдань. Студенти із високим рівнем володіння мовою отримуватимуть більш складні завдання, що допоможе запобігти їхьому розчаруванню стосовно того, що вони не розвиваються та не рухаються вперед.

Важливо створювати образ педагога як людини, мета якої - допомогти опанувати 
нові знання та навички, підтримати в разі виникнення труднощів. Складниками образу викладача $€$ зовнішній вигляд, темперамент, риси характеру, стиль управління студентами, знання предмета та сучасних методів викладання, висока духовність, моральність, справедливість, уміння керувати своїми емоціями, уміння забезпечувати зворотний зв'язок зі студентами, готовність допомогти та підтримати студентів, уміння не тільки вислухати, але й почути студента, вербальна та невербальна поведінка, уміння створити позитивну емоційну атмосферу на занятті. Уміння розпізнавати емоційний стан студентів, обговорювати його, з'ясувати причини та можливість позитивно на нього впливати сприятиме розвитку емоційного інтелекту студентів. Емоційність заняття підвищується, якщо викладач стоїть над навчальним процесом, правильно його організовує та керує ним, але в жодному разі не перебуває поза цим процесом.

Необхідно бути готовим емоційно підтримати студентів у разі стійкого поганого настрою, нападів злості, страху, тривоги без наявних зовнішніх стимулів.

Отже, у статті проаналізовані праці вчених, присвячені визначенню та класифікації емоцій, опису трьох ключових елементів емоцій, як-от: суб'єктивне сприймання, фізіологічна реакція та поведінкова відповідь. У статті дано визначення емоційного інтелекту, визначені його складники, описані риси студентів, які мають високий емоційний інтелект. Дано рекомендації щодо формування емоційного інтелекту у студентів ЗВО на заняттях з іноземної мови.

\section{ЛІТЕРАТУРА:}

1. Лабунская В. Невербальное поведение. Ростов-на-Дону : Изд-во Ростовского ун-та, 1986. $135 \mathrm{C}$.

2. Симоненков А., Клюжев В. Синдром серотониновой недостаточности. Москва : Бином, 2013. 96 с.

3. The Experience of Emotion / L. Barrett et al. Annual Review of Psychology. 2007. Vol. 58. P. 373-403.

4. Chaouloff F. Serotonin, stress and corticoids. Journal of Psychopharmacology. 2000. Vol. 14. № 2. P. 139-151.

5. Dunlop K., Liston C. Stress response regulation and the hemodynamic response. Proceedings of the National Academy of Sciences. 2018. Vol. 115. № 43. P. 10827-10829.

6. Eckman P. Basic Emotions. Handbook of cognition and Emotion. 2005. P. 45-90.

7. Fallahzadeh $H$. The relationship between emotional intelligence and academic achievement in medical science students in Iran. Procedia-social and Behavioral Sciences. 2011. Vol. 30. P. 1461-1466.

8. Hockenbury D., Hockebury S. Discovering Psychology. New York: Worth Publishers, 2007.

9. Self-talk as a regulatory mechanism: How you do it matters / E. Kross et al. Journal of personality and social psychology. 2014. Vol. 106 (2). P. 304.

10. Mulder M., Nijholt A. Humour research. State of the art. Twente, The Netherlands : Centre for Telematics and information Technology (CTIT), 2002. Vol. 2. 24 p.

11. Plutchik R. In search of the basic emotions. Handbook of Cognition and Emotion. Contemporary Psychology: A Journal of Reviews. 1984. № 29 (6). P. 511-513.

12. Pessoa L. Emotion and cognition and the amygdale: from "what is it?" to "what's to be done?". Neuropsychologia. 2010. Vol. 48 (12). P. 3416-3429. 